DOI: $10.21802 / \operatorname{artm} .2019 .4 .12 .18$.

УДК 616.839-06:616.314-008.17-053.7/.82

\title{
СТАН АВТОНОМНОЇ РЕГУЛЯЦІЇ У МОЛОДИХ ОСІБ ІЗ ЗАПАЛЬНИМИ ЗАХВОРЮВАННЯМИ ПАРОДОНТА
}

\author{
С.Н. Вадзюк, Ю.В. Болюк, І.Я. Папінко
}

Тернопільський національний медичний університет імені І.Я. Горбачевського, кафедра фізіології з основами біоетики та біобезпеки, м. Тернопіль, Украӥна,

ORCID ID: 0000-0001-9105-8205, e-mail:vadzyuk@tdmu.edu.ua,

ORCID ID: 0000-0002-1678-9208,e-mail:boliuk@tdmu.edu.ua,

ORCID ID: 0000-0001-6129-0097, e-mail:papinko@tdmu.edu.ua

Резюме. Відомо, що автономна регуляція відіграє важливу роль у підтримці сталості внутрішнього середовища, а також бере участь у процесах адаптації до різних несприятливих факторів. Варіабельність серцевого ритму - це сукупність кількісних параметрів, що дозволяє оцінювати стан автономної регуляції усіх процесів в організмі загалом.

Метою даної роботи було встановити залежність між станом автономної регуляції та запальними захворюваннями пародонта.

Матеріали та методи. Було обстежено 138 студентів Тернопільського національного медичного університету імені І. Я. Горбачевського МОЗ України. Сформовано дві групи: 70 осіб - із запальними захворюваннями пародонта, а саме хронічним катаральним гінгівітом; 68 - пародонтологічно здорових. Стан автономної регуляції оцінювали за допомогою математичного аналізу серцевого ритму з використанням приладу «Поли-Спектр-8Е/8В» та комп'ютерного програмного комплексу «Поли-Спектр» із застосуванням статистичного, спектрального методів та кардіоінтервалографії за Р. М. Баєвським. Реєстрацію ритмограми проводили у короткому режимі (5 хв). Безпосередньо перед записом обстежуваний лежав у спокійному стані протягом 10 хв.

Результати. У ході роботи виявлено тенденцію до зниження загального тонусу автономної регуляції серцевого ритму в обстежених із пародонтопатологією. Спостерігалось підвищення частки низькочастотних коливань у загальній потужності спектру, що свідчить про зростання симпатичної модуляції у студентів із ураженим пародонтом. Також зареєстровано значне зменшення потужності високочастотних коливань, що вказує на зниження впливу парасимпатичної ланки автономної нервової системи на серцевий ритм у молодих людей.

Висновки. Таким чином, в осіб із запальними захворюваннями пародонта зафіксовано зміщення симпато-вагального балансу у бік симпатичної регуляції, що свідчить про значний вплив таких зсувів на розвиток досліджуваної патології.

Ключові слова: пародонт; захворювання тканин пародонта; автономна регуляція; варіабельність серцевого ритму.

Вступ. Хвороби пародонта займають друге місце за поширеністю серед стоматологічних захворювань [1]. Вони є однією з основних причин ранньої втрати зубів, що у свою чергу може призвести і до серйозних порушень функції шлунково-кишкового тракту [2-4]. Особливої уваги заслуговує зростання частоти уражень пародонта серед осіб молодого віку [5]. Тому необхідним $є$ створення ефективних методів формування груп ризику та способів ранньої діагностики. Це вимагає всебічного вивчення патогенезу пародонтопатологій, а також впливів різних індивідуальних особливостей організму на їх розвиток.

Як відомо, автономна нервова система бере участь у підтримці сталості внутрішнього середовища та відіграє важливу роль у процесах адаптації до несприятливих екзогенних та ендогенних чинників. ÏÏ стан впливає на клінічний перебіг багатьох хвороб. Характер цього впливу залежить від переважання симпатичної чи парасимпатичної регуляції [5-7].

Тому доцільним $\epsilon$ визначення взаємозв'язків між станом автономної нервової системи та захворюваннями тканин пародонта.
Обгрунтування дослідження. За даними літературних джерел захворювання тканин пародонта $\epsilon$ поліетіологічними. На розвиток цієї патології впливають різноманітні чинники, які можуть поєднуватися один 3 одним. Серед них стан гігієни ротової порожнини, генетична схильність, наявність хронічних соматичних захворювань [8-10]. Описана також роль автономної регуляції у порушенні мікроциркуляції у тканинах пародонта, що призводить до розвитку запальних та дистрофічних уражень. Встановлено, що в осіб із генералізованим пародонтитом переважає вплив симпатичної ланки автономної нервової системи [10]. Однак недостатньо даних про стан автономної регуляції при запальних захворюваннях тканин пародонта, що фактично передують розвитку генералізованого пародонтиту [11].

У деяких роботах висвітлено особливості автономної регуляції при пародонтологічних захворюваннях у поєднанні із соматичною патологією серед людей молодого [5], а також зрілого та літнього віку [12]. Зокрема вивчено і стан автономної нервової системи в осіб із запальними ураженнями пародонта 
на фоні хвороб шлунково-кишкового тракту [13]. Проте у даних дослідженнях для оцінювання автономної регуляції використовували індекс Кердо та Хільдебранта, вегетативний індекс, а також опитувальник Вейна. На базі нашої лабораторії раніше досліджено вплив регуляторних зміщень на розвиток та перебіг запальних захворювань тканин пародонта у дітей $з$ використанням математичного аналізу серцевого ритму [14]. Однак залишається нез'ясованою роль автономної нервової системи у розвитку пародонтопатології саме серед молодих людей, а особливо без супутніх соматичних захворювань.

Тому, на нашу думку, доцільно глибше вивчити взаємозв'язки між особливостями автономних впливів та захворюваннями пародонта.

Мета роботи. Виявити залежність між особливостями автономної регуляції серцевого ритму та запальними захворюваннями пародонта серед студентів.

Матеріали та методи. Дослідження проводили на базі атестованої MO3 України лабораторії психофізіологічних досліджень кафедри фізіології 3 основами біоетики та біобезпеки Тернопільського національного медичного університету імені I. Я. Горбачевського МО3 України (Свідоцтво № 055/13) та кафедри терапевтичної стоматології цього ж університету. У ході роботи дотримувались біоетичних норм Гельсінської декларації Всесвітньої медичної асоціації «Етичні принципи медичних досліджень за участю людини у якості об'єкта дослідження» (прийнята 59-ою Генеральною асамблеєю, перегляд від жовтня 2008 року), Міжнародного кодексу медичної етики та законів України (рішення комісії 3 біоетики ДВНЗ «Тернопільський державний медичний університет імені І. Я. Горбачевського МO3 України», протокол №54 від 27 серпня 2019 р.).

У дослідженні взяли участь 138 осіб віком 1823 років, що навчаються у Тернопільському національному медичному університеті імені I. Я. Горбачевського МO3 України, без хронічних соматичних захворювань. Серед них 70 із встановленим діагнозом хронічного катарального гінгівіту (основна група) та 68 із здоровим пародонтом (контрольна група).

Стан автономної регуляції визначали за допомогою математичного аналізу серцевого ритму. Для цього використовували прилад «Поли-Спектр8E/8В» та комп'ютерний програмний комплекс «Поли-Спектр». Реєстрацію ритмограми проводили у короткому режимі $(5 \mathrm{xв})$. Безпосередньо перед записом обстежуваний лежав у спокійному стані протягом 10 хв. Далі за допомогою програми здійснювали статистичний та спектральний аналіз, а також кардіоінтервалографію за Р. М. Баєвським $[15,16]$.

Статистичний аналіз серцевого ритму передбачав розрахунок таких показників:

SDNN - стандартне відхилення (SD) величин нормальних інтервалів R-R;
RMSSD - квадратний корінь із середнього квадратів різниць величин послідовних пар нормальних інтервалів R-R;

pNN50 - частка послідовних нормальних інтервалів $\mathrm{R}-\mathrm{R}$, різниця між якими перевищує 50 мс.

При проведенні спектрального аналізу враховували значення:

ТP - загальна потужність спектру (діапазон частот $0,003-0,4$ Гц);

VLF - потужність коливань дуже низької частоти (0,003-0,04 Гц);

LF - потужність коливань у низьких діапазонах частот $(0,04-0,15$ Гц);

HF - потужність високочастотних коливань $(0,15$ 0,4 Гц);

\% VLF - відносний показник потужності коливань дуже низької частоти;

\% LF - відносний показник потужності низькочастотних коливань;

\% HF- відносний показник потужності коливань високих діапазонів частот;

LF/HF - симпато-вагальний індекс.

За допомогою кардіоінтервалографії визначали:

варіаційний розмах (BР) - різниця між максимальним та мінімальним значеннями R-R;

амплітуду моди (АМо) - кількість кардіоінтервалів у \%, що відповідають діапазону моди;

індекс вегетативної рівноваги (IBP) - відношення амплітуди моди до варіаційного розмаху;

вегетативний показник ритму (ВПР) - обернене значення добутку моди та варіаційного розмаху.

Таким чином, для оцінки механізмів регуляції в цілому брали до уваги показники SDNN та TP. Аналіз рівнів симпатичної регуляції здійснювали, базуючись на значеннях LF, \% LF та AMo, а парасимпатичної регуляції - RMSSD, pNN50, HF, \% HF, ВР та ВПР. Гуморальну ланку регуляції оцінювали за показником VLF, \% VLF. Визначення балансу симпатичної та парасимпатичної активності проводили, враховуючи значення LF/HF та IBP.

Статистичний аналіз отриманих даних здійснювали 3 використанням ліцензійного програмного статистичного пакету StatPlus 6 (AnalystSoft Inc., номер ліцензії 11114110). Визначали нормальність розподілу даних у вибірках за методом Shapiro-Wilk. Для оцінювання достовірності різниці у групах дослідження між показниками із ненормальним розподілом використовували непараметричний Uкритерій Mann-Whitney. Значущість відмінностей між даними з нормальним розподілом визначали за допомогою однофакторного дисперсійного аналізу ANOVA.

Результати дослідження. Статистичний аналіз варіабельності серцевого ритму показав достовірну різницю між значеннями SDNN у групах дослідження $(p=0,0298)$. Спостерігались вірогідно нижчі рівні SDNN серед молодих людей із запальними захворюваннями пародонта, як порівнювати 3 контрольною групою (рис. 1). 


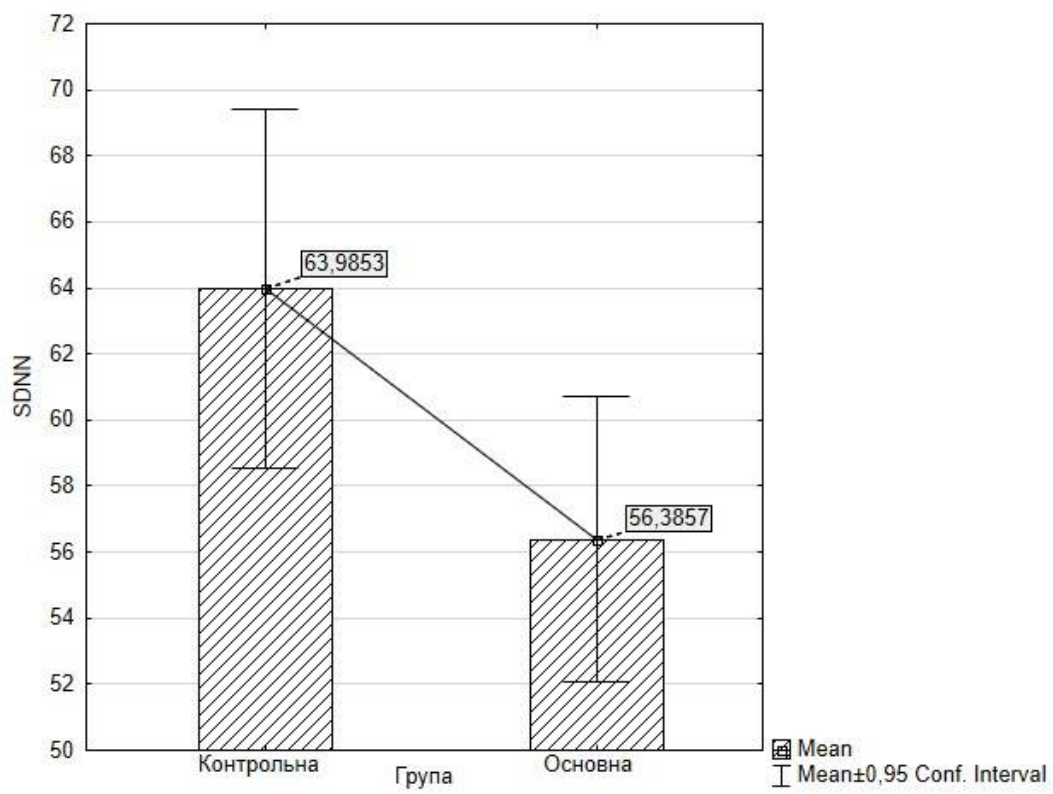

Рис. 1. Середні значення SDNN (мс)

Значення RMSSD також були достовірно нижчими у студентів основної групи, ніж у групі контролю. Однак не виявлено значущої різниці у групах дослідження за pNN50, хоча показники були нижчими в осіб із ураженим пародонтом (табл. 1).

Схожа тенденція простежувалася за результатами спектрального аналізу. Загальна потужність спектру у молодих людей основної групи була на нижчому рівні, ніж серед обстежених контрольної групи. Проте вірогідності даних відмінностей не підтверджено (див. табл. 1).

Також виявлено істотну різницю між значеннями VLF у досліджуваних групах. Серед студентів основної групи зареєстровано зниження потужності коливань дуже низької частоти. У той же час за відносним параметром \% VLF, що відображає частку коливань дуже низької частоти у загальній потужності спектру, не спостерігалося значущої відмінності. Показники LF в осіб із ураженим пародонтом не відрізнялися від таких у контрольній групі. Проте відсоток низькочастотних коливань у сумарній потужності був на достовірно вищому рівні у молодих людей із ураженим пародонтом. Також зафіксовано вірогідно нижчі значення HF в обстежених із патологією пародонта, ніж серед пародонтологічно здорових. Аналогічно значуща відмінність спостерігалася за параметром \% HF. Частка високочастотних коливань у загальній потужності спектру була істотно вищою у контрольній групі (див. табл. 1).

Показники варіабельності серцевого ритму за результатами статистичного, спектрального аналізу та кардіоінтервалографії за Р. М. Баєвським

\begin{tabular}{|c|c|c|c|c|c|c|c|}
\hline \multirow{2}{*}{ Показник } & $\mathbf{M}$ & Медіана & $\mathbf{m}$ & $\mathbf{M}$ & Медіана & $\mathbf{M}$ & \multirow{2}{*}{$\mathbf{p}$} \\
\hline & \multicolumn{3}{|c|}{ Контрольна група (n=68) } & \multicolumn{3}{|c|}{ Основна група (n=70) } & \\
\hline RMSSD, мс & 59,191 & 57,000 & 3,006 & 51,257 & 46,000 & 3,019 & $* 0,0417$ \\
\hline $\mathrm{pNN} 50, \%$ & 30,033 & 32,500 & 2,017 & 25,838 & 22,300 & 2,353 & 0,0827 \\
\hline $\mathrm{TP}, \mathrm{Mc}^{2}$ & 5081,926 & 4282,000 & 412,148 & 3899,771 & 3443,000 & 251,844 & 0,0719 \\
\hline VLF, $\mathrm{Mc}^{2}$ & 1696,147 & 1142,000 & 154,209 & 1205,056 & 955,000 & 96,127 & $* 0,0310$ \\
\hline $\mathrm{LF}, \mathrm{Mc}^{2}$ & 1439,324 & 1053,500 & 142,762 & 1161,737 & 1032,500 & 80,349 & 0,4716 \\
\hline $\mathrm{HF}, \mathrm{Mc}^{2}$ & 1946,515 & 1631,500 & 176,110 & 1280,877 & 1065,000 & 116,058 & $* 0,0029$ \\
\hline$\%$ VLF, $\%$ & 34,134 & 34,000 & 1,502 & 33,843 & 32,350 & 1,657 & 0,8969 \\
\hline$\% \mathrm{LF}, \%$ & 28,126 & 27,550 & 1,153 & 32,989 & 33,200 & 1,117 & $* 0,0029$ \\
\hline$\% \mathrm{HF}, \%$ & 37,784 & 36,000 & 1,452 & 33,093 & 32,400 & 1,842 & $* 0,0187$ \\
\hline $\mathrm{BP}, \mathrm{c}$ & 0,456 & 0,407 & 0,024 & 0,390 & 0,366 & 0,018 & 0,0628 \\
\hline AMo, $\%$ & 35,532 & 35,700 & 1,179 & 39,606 & 38,000 & 1,383 & 0,0609 \\
\hline ВПР, ум. од. & 3,223 & 2,915 & 0,193 & 3,788 & 3,260 & 0,219 & 0,0794 \\
\hline
\end{tabular}

Примітки: $\mathrm{M}$ - середнє значення показника; $\mathrm{m}$ - стандартна похибка;

* - вірогідна відмінність між показниками у групах дослідження $(\mathrm{p}<0,05)$. 
Достовірну різницю виявлено і за показниками симпато-вагального індексу $(\mathrm{p}=0,0004)$. Так, у студентів із запальними захворюваннями пародонта реєстрували істотно вищі значення LF/HF, якщо порівнювати із групою контролю (рис. 2).

За допомогою кардіоінтервалографії за Р. М. Баєвським було підтверджено вищенаведені результати. Між групами дослідження спостерігалася стати- стично вірогідна відмінність за IBP $(p=0,0361)$. Даний показник в осіб із патологією пародонта був значно вищим, ніж у студентів контрольної групи (рис. 3). Достовірної різниці за іншими параметрами не виявлено. Хоча у молодих людей із ураженим пародонтом простежувалися нижчі рівні ВР та вищі - АМо і ВПР, якщо порівнювати 3 пародонтологічно здоровими (див. табл. 1).

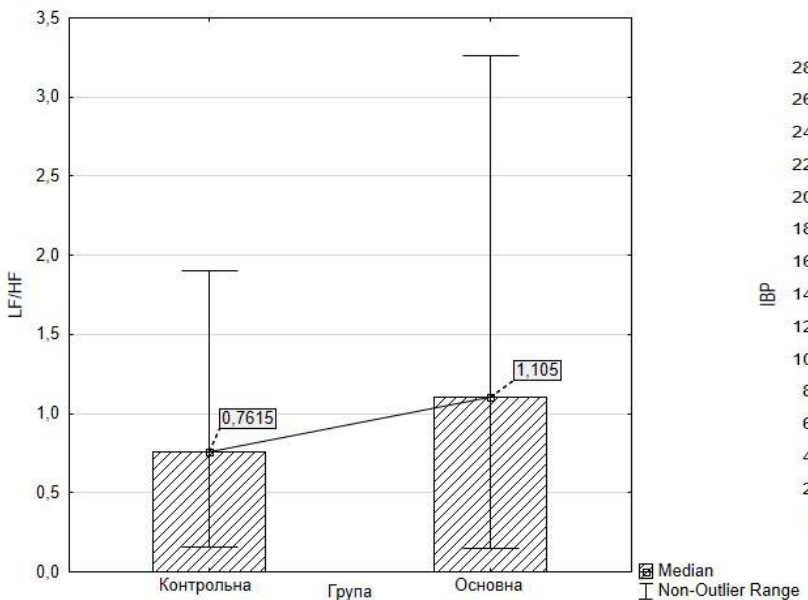

Рис. 2. Рівні LF/HF у групах дослідження (ум. од.)

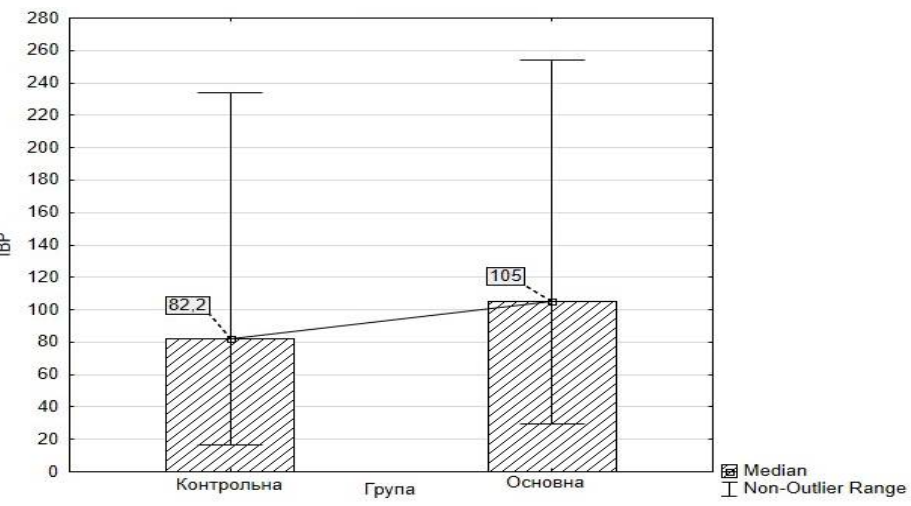

Рис. 3. Показники IBP (ум. од.)
Обговорення результатів. Варіабельність серцевого ритму - це природні зміни інтервалів між серцевими скороченнями нормального синусового ритму серця. Послідовний ряд кардіоінтервалів має складну структуру, що відображає регуляторний вплив на синусний вузол серця автономної нервової системи і різних гуморальних факторів. Тому аналіз структури варіабельності серцевого ритму надає важливу інформацію про стан автономної регуляції в організмі загалом. Характеристика серцевого ритму це один із найбільш інформативних методів кількісного оцінювання стану автономної нервової системи. Зокрема вона дозволяє визначити зміни балансу симпатичного та парасимпатичного відділів. Активність даних ланок автономної нервової системи $\epsilon$ результатом багаторівневої інтегративної регуляції кровообігу. У межах цієї системи відбувається зміна певних параметрів, що відображає адаптаційні реакції цілого організму [16,17].

Одним із найчутливіших показників варіабельності серцевого ритму, що має прогностичне значення, є SDNN. Даний параметр характеризує стан регуляторних механізмів загалом і відображає вплив на синусовий вузол як симпатичного, так і парасимпатичного відділів автономної нервової системи [18]. При проведенні нашого дослідження виявлено зниження рівня SDNN у молодих людей із пародонтологічними захворюваннями, що за даними деяких джерел свідчить про зміщення балансу автономної регуляції на користь симпатичного контуру [15].

RMSSD та pNN50 вказують переважно на парасимпатичний тонус, відображаючи короткотермінову зміну частоти серцевого ритму. У нашому випадку в основній групі спостерігалися нижчі значення RMSSD. Звідси випливає, що в осіб із пато- логією пародонта істотно зменшена частка парасимпатичної ланки у регуляції серцевого ритму.

Зниження показників ТР в осіб із запальними захворюваннями пародонта свідчить про зменшення сумарного впливу автономної нервової системи на серцевий ритм. \% VLF не відрізнявся у групах дослідження, що вказує на однакову роль гуморальних факторів у регуляції серцевого ритму в обох групах. Різниці між потужностями низькочастотних коливань не виявлено. Однак спостерігалось переважання відносного показника \% LF в осіб із запальними захворюваннями пародонта. Це вказує на переважання симпатичної модуляції у студентів основної групи. Зниження потужності у діапазоні високих частот, а також частки високочастотних коливань у загальній потужності спектру, свідчить про зменшення ролі парасимпатичного контуру у регуляції серцевого ритму серед молодих людей із патологією пародонта. Крім того, у ході роботи виявлено вищі значення симпато-вагального індексу в основній групі, що відображає зміщення автономної рівноваги у бік симпатичної активності.

Індекс вегетативної рівноваги вказує на співвідношення між активністю симпатичного та парасимпатичного відділів. Зростання IBP в основній групі свідчить про збільшення впливу симпатичної ланки автономної нервової системи на серцевий ритм.

У багатьох наукових джерелах описано вплив автономної нервової системи на слиновиділення. Відомо, що при підвищеній активності симпатоадреналової системи, суттєво зменшується об'єм продукції слини [19]. При цьому вона стає густішою (зменшується частка води та збільшується продукція ферментів), що зумовлює погіршення механічного очищення міжзубних проміжків, сприяє накопиченню 
та розмноженню бактерій, порушенню трофіки та травматизації слизової. Крім того, деякі дослідники зауважують, що зростання кількості протеїнів спричиняє затримання кальцію, що у свою чергу призводить до утворення зубного каменю, який є місцевим травматичним і ретенційним фактором [20].

Також активація симпатичної ланки нервової системи супроводжується підвищенням тонусу судин i загального судинного опору, сприяє негативним метаболічним, трофічним, гемодинамічним i peологічним змінам у тканинах пародонта [10].

Тому, на нашу думку, зміщення балансу автономної регуляції у бік симпатичних впливів, сприяє розвитку запальних захворювань пародонта. Слід також зауважити, що такі зміни параметрів варіабельності серцевого ритму разом із загальним зниженням тонусу автономної регуляції, відображають адаптаційну реакцію організму на будь-які екзогенні чи ендогенні впливи. Звідси випливає, що наявність запального ураження тканин пародонта, може у свою чергу викликати зміни варіабельності серцевого ритмy.

\section{Висновки:}

1. У студентів із запальними захворюваннями пародонта виявлено сумарне зниження впливу регуляторних механізмів порівняно з контрольною групою, про що свідчить зменшення показників SDNN та TP.

2. В осіб із ураженим пародонтом спостерігається зниження частки впливу парасимпатичної ланки автономної регуляції, на що вказують менші значення RMSSD, HF i \%HF.

3. У молодих людей із патологією пародонта виявлено переважання симпатичної модуляції, про що свідчить зростання відносного показника \% $\mathrm{LF}$.

4. Не спостерігалося зміщень з боку гуморальних впливів, на що вказує однакова частка \%VLF.

5. В осіб із запальними захворюваннями пародонта виявлено зміщення автономної рівноваги у бік симпатичної ланки, про що свідчать вищі значення симпато-вагального індексу та індексу вегетативної рівноваги.

\section{References:}

1. Boichenko OM, Sidash YuV. Poshyrenist zakhvoriuvannia tkanyn parodonta u khvorykh na IKhS. [Extended reliability of periodontal tissues in patients with coronary heart disease]. VISNYK VDNZU «Ukrainska medychna stomatolohichna akademiia». 2013; 13:13-5.

2. Zhang S, Yu P, Wang JB, Fan JH, Qiao YL, Taylor PR. Association between tooth loss and upper gastrointestinal cancer: A 30-year follow-up of the Linxian Dysplasia Nutrition Intervention Trial Cohort. Thorac Cancer. 2019; 10:966-74.

3. Lee D, Jung KU, Kim HO, Kim H, Chun HK. Association between oral health and colorectal adenoma in a screening population. Med (United States). 2018. P.97.

4. Ndegwa N, Ploner A, Liu Z, Roosaar A, Axéll T, Ye W. Association between poor oral health and gastric cancer: A prospective cohort study. Int J Cancer. 2018; 143:2281-8.

5. Sloboda MT. Rezultaty doslidzhennia pokaznykiv vehetatyvnoi nervovoi systemy pry urazhenniakh tkanyn parodonta $\mathrm{V}$ osib molodoho viku $\mathrm{z}$ deformuiuchymy dorsopatiiamy. [The results of the study of autonomic nervous system indicators in young people with lesions of periodontal tissues and deformable dorsopathies]. Odeskyi medychnyi zhurnal. 2016. P.54-8.

6. Batih VM. Viddaleni rezultaty kompleksnoho likuvannia khvorykh iz khronichnym perebihom heneralizovanoho parodontytu ta perevazhanniam parasympatychnoi vehetatyvnoi nervovoi systemy. [Long-term results of complex treatment of patients with chronic course of generalized periodontitis and predominance of parasympathetic autonomic nervous system]. Sovremennaia stomatolohyia. 2018. P.32-6.

7. Polstianoi AO, Fedorchenko MO, Romaniuk MH. Suchasnyi naukovyi pohliad na sklad sympatychnoi ta parasympatychnoi chastyn vehetatyvnoi nervovoi systemy: literaturnyi ohliad. [Contemporary scientific perspective on the composition of the sympathetic and parasympathetic parts of the autonomic nervous system: a literature review]. Molodyi vchenyi. 2017; 11(51):96-9.

8. AlJehani YA, Bansal M, Rastogi S, Vineeth NS. Risk factors of periodontal disease: review of the literature. Int J Dent. 2013;126-30.

9. Kinane DF, Stathopoulou PG, Papapanou PN. Periodontal diseases. Nat Rev Dis Prim. 2017;(3):1-14.

10. Romanenko IG, Krjuchkov DJu. Generalizovannyj parodontit i metabolicheskij sindrom. Edinstvo patogeneticheskih mehanizmov razvitija. [Generalized periodontitis and metabolic syndrome. The unity of pathogenetic mechanisms of development]. Krims'kij terapevtichnij zhurnal. 2011; 1:60-7.

11. Cepov LM, Nikolaev AI, Nesterova MM, Petrova EV. Hronicheskij generalizovannyj kataral'nyj gingivit i hronicheskij generalizovannyj parodontit: obshhie istoki, posledovatel'nyj perehod? (Diskussija). [Chronic generalized catarrhal gingivitis and chronic generalized periodontitis: common sources, sequential transition? (Discussion)]. Vestnik Smolenskoj gosudarstvennoj medicinskoj akademii. 2018; 17(3):198-205.

12. Tepla TO. Osoblyvosti perebihu, likuvannia i profilaktyky zakhvoriuvan tkanyn parodonta $\mathrm{u}$ patsiientiv $\mathrm{z}$ urazhenniam mizhkhrebtsevykh dyskiv shyinoho viddilu [dysertatsiia]. [Features of the course, treatment and prevention of periodontal tissue diseases in patients with lesions of the cervical intervertebral discs (dissertation)]. Vinnytskyi natsionalnyi medychnyi universytet im. M. I. Pyrohova; 2017.

13. Luchynskyi MA, Yastremskyi VM. Otsinka stanu vehetatyvnoi nervovoi systemy $\mathrm{u}$ patsiientiv $\mathrm{z}$ odontohennymy zapalnymy protsesamy na foni khvorob shlunkovo-kyshkovoho traktu $\mathrm{z}$ pomirnym stupenem tryvohy. [Assessment of the autonomic nervous system in patients with odontogenic inflammatory processes and underlying moderate gastrointestinal disorders]. Klinichna stomatolohiia. 2015. P.79-83.

14. Vadziuk S, Palasiuk B, Yasnii O. Avtonomna rehuliatsiia $\mathrm{V}$ ditei starshoho shkilnoho viku $\mathrm{z}$ riznym rivnem tryvozhnosti. [Autonomous regulation in older children with different levels of anxiety]. Buk. 2013; 17:23-7.

15. Kovalenko S, Kudii L. Variabelnist sertsevoho rytmu. Metodychni aspekty. [Heart rate variability. Methodical aspects]. Cherkasy: Cherkaskyi natsionalnyi universytet im. B. Khmelnytskoho; 2016. 
16. Korkushko O, Pisaruk A, Shatilo V, Lishnevskaja $\mathrm{V}$, Chebotarev N, Pogoreckij Ju. Analiz variabelnosti ritma serdca $\mathrm{v}$ klinicheskoj praktike (Vozrastnye aspekty). [Analysis of heart rate variability in clinical practice (Age aspects)]. Kiev; 2002.

17. Holdovskyi BM, Potalov SO, Sid YeV, Serikov KV, Nasteka NV. Vplyv stresu na pokaznyky variabelnosti sertsevoho rytmu $\mathrm{v}$ spivrobitnykiv vyiznoho personalu shvydkoi medychnoi dopomohy. [Effect of stress on indicators of heart rate variability in emergency medical staff]. Medytsyna nevidkladnykh staniv. 2015. P.92-5.

18. Boiarska LM, Kravets LV, Ivanova KO. Osoblyvosti formuvannia funktsionalnykh mozhlyvostei vehetatyvnoi nervovoi systemy u ditei shcho narodylys peredchasno. [Features of development of autonomic nervous functional capabilities system in children born prematurely]. Visnyk problem biolohii i medytsyny. 2018; 2(143):89-94.

19. Punj A. Secretions of Human Salivary Gland. Salivary Gland - New Approaches Diagnostics Treat. IntechOpen; 2019.

20. Jarova SP, Sanojan VV. Rol' sljuny v razvitii i techenii vospalitel'nyh zabolevanij parodonta. [The role of saliva in the development and course of inflammatory periodontal diseases]. Visnyk Ukrainskoi medychnoi stomatolohichnoi akademii «Aktualni problemy suchasnoi medytsyny». 2007; 7(3):212-7.

\section{УДК 616.839-06:616.314-008.17-053.7/.82 СОСТОЯНИЕ АВТОНОМНОЙ РЕГУЛЯЦИИ У МОЛОДЫХ ЛИЦ С ВОСПАЛИТЕЛЬНЫМИ ЗАБОЛЕВАНИЯМИ ПАРОДОНТА}

\section{С.Н. Вадзюк, Ю.В. Болюк, И.Я. Папинко}

Тернопольский национальный медицинский университет им. И. Я. Горбачевского, кафедра физиологии с основами биоэтики и биобезопасности,

2. Тернополь, Украина,

ORCID ID: 0000-0001-9105-8205,

e-mail:vadzyuk@tdmu.edu.ua,

ORCID ID: 0000-0002-1678-9208,

e-mail:boliuk@tdmu.edu.ua,

ORCID ID: 0000-0001-6129-0097,

e-mail:papinko@tdmu.edu.ua

Резюме. Известно, что автономная нервная система играет важную роль в поддержании постоянства внутренней среды, а также участвует в процесcax адаптации к различным неблагоприятным факторам. Вариабельность сердечного ритма - это совокупность количественных параметров, позволяет оценивать состояние автономной регуляции ритма сердца, а следовательно и воздействий автономной нервной системы на организм в целом.

Целью данной работы было установление зависимости между состоянием вегетативной нервной системы и заболеваниями пародонта.

Материалы и методы. Было обследовано 138 студентов Тернопольского национального меди- цинского университета имени И. Я. Горбачевского MO3 Украины. Сформированы две группы: 70 человек - с воспалительными заболеваниями пародонта, а именно хроническим катаральным гингивитом; 68 пародонтологически здоровых. Состояние автономной нервной системы оценивали с помощью анализа вариабельности сердечного ритма с использованием прибора «Поли-Спектр-8Е/8В» и компьютерного программного комплекса «Поли-Спектр» и применением статистического, спектрального методов и кардиоинтервалографии по Р. М. Баевскому. Регистрацию электрокардиограммы проводили в коротком режиме (5 мин). Непосредственно перед записью обследуемый лежал в спокойном состоянии в течение 10 мин.

Результаты. Выявлена тенденция к снижению общего тонуса автономной регуляции сердечного ритма у обследованных с пародонтопатологией. Наблюдалось повышение доли низкочастотных колебаний в общей мощности спектра, что свидетельствует о росте симпатической модуляции студентов с пораженным пародонтом. Также зарегистрировано уменьшение мощности высокочастотных колебаний, что указывает на снижение влияния парасимпатического звена вегетативной нервной системы на сердечный ритм у молодых людей.

Выводы. Таким образом, у лиц с воспалительными заболеваниями пародонта зафиксировано смещение симпато-вагального баланса в сторону симпатической регуляции.

Ключевые слова: пародонт; заболевания тканей пародонта; автономная регуляция; вариабельность сердечного ритма.

\section{UDC 616.839-06:616.314-008.17-053.7/.82 \\ STATE OF AUTONOMIC REGULATION IN YOUNG SUBJECTS WITH INFLAMMATORY PERIODONTAL DISEASES}

\author{
S.N. Vadzyuk, Yu.V. Boliuk, I.Ya. Papinko
}

I. Horbachevsky Ternopil National Medical University, Department of Physiology with basics of Bioethics and Biosafety, Ternopil, Ukraine,

ORCID ID: 0000-0001-9105-8205,

e-mail:vadzyuk@tdmu.edu.ua,

ORCID ID:0000-0002-1678-9208,

e-mail:boliuk@tdmu.edu.ua,

ORCID ID: 0000-0001-6129-0097,

e-mail:papinko@tdmu.edu.ua

Abstract. It is known that the autonomic nervous system plays an important role in maintaining the sustainability of the internal environment, and also participates in the processes of adaptation to various adverse factors. Its condition affects the clinical course of many diseases. The nature of this effect depends on the predominance of sympathetic or parasympathetic regulation. Heart rate variability is a set of quantitative parameters that allows to evaluate the state of autonomic regulation 
of heart rhythm, and therefore the effects of the autonomic nervous system on the body as a whole.

The purpose of this work is to establish the relationship between the state of the autonomic nervous system and periodontal diseases.

Materials and methods. 138 students of I. Horbachevsky Ternopil National Medical University of the Ministry of Health of Ukraine were surveyed. Two groups were formed: 70 people with inflammatory periodontal diseases, namely chronic catarrhal gingivitis, and 68 people without periodontal diseases. The state of the autonomic nervous system was evaluated by analysis of heart rate variability using the Poly-Spectr-8E/8B devise and the Poly-Spectr computer software complex. For this purpose, statistical, spectral methods and cardiointervalography by R.M Bayevsky were used. Electrocardiogram registration was performed in short mode $(5 \mathrm{~min})$. Immediately before recording, the subject was in a calm state for $10 \mathrm{~min}$.

Results. One of the most sensitive indicators of heart rate variability that is prognostic is SDNN. This parameter characterizes the state of regulatory mechanisms as a whole and reflects the effect on the sinus node of both the sympathetic and parasympathetic parts of the autonomic nervous system. Our study revealed a decrease in the level of SDNN in young people with periodontal disease, which indicates a shift in the balance of autonomous regulation in favor of the sympathetic circuit.

RMSSD and pNN50 mainly indicate parasympathetic tone, reflecting a short-term change in heart rate. In our case, lower RMSSD values were observed in the main group. It follows that the proportion of the parasympathetic link in the regulation of cardiac rhythm is significantly reduced in subjects with periodontal pathology.

The decrease in total power in subjects with inflammatory periodontal disease indicates a decrease in the total effect of the autonomic nervous system on heart rate. No differences were found between the lowfrequency oscillation power. However, there was a predominance of the relative values of low-frequency oscillation capacities in students with periodontal inflammatory disease. This indicates the predominance of sympathetic modulation in the main group. The decrease in power in the high-frequency range, as well as the share of highfrequency oscillations in the total power of the spectrum, indicates a decrease in the role of the parasympathetic part in the regulation of cardiac rhythm among young people with periodontal pathology. In addition, the work revealed higher values of the sympathetic oscillation index in the main group, which reflects the shift of autonomous equilibrium towards sympathetic activity.

The vegetative equilibrium index indicates the correlation between the activity of the sympathetic and parasympathetic compartments. The growth of vegetative equilibrium index in the main group indicates an increase in the influence of the sympathetic link of the autonomic nervous system on the heart rhythm.

Conclusions. Thus, the results of the analysis of heart rate variability revealed that young people with inflammatory periodontal diseases are characterized by a shift in autonomic regulation toward the predominance of sympathetic influences.

Keywords: periodontium; periodontal diseases; autonomous regulation; heart rate variability.

Стаття надійшла в редакцію 31.10.2019 р. 